\section{Intersections}

Canadian Journal of Music

Revue canadienne de musique
Intersections CANADIAN JOURAL OF MUSIO

\title{
The Wild Hunter, the Wandering Jew, and the Flying Dutchman: The Hunt In Wagner's Der fliegende Holländer
}

\section{J. Drew Stephen}

Volume 33, numéro 2, 2013

Musical Perspectives, People, and Places: Essays in Honour of Carl Morey

URI : https://id.erudit.org/iderudit/1032693ar

DOI : https://doi.org/10.7202/1032693ar

Aller au sommaire du numéro

Éditeur(s)

Canadian University Music Society / Société de musique des universités canadiennes

ISSN

1911-0146 (imprimé)

1918-512X (numérique)

Découvrir la revue

Citer cet article

Stephen, J. D. (2013). The Wild Hunter, the Wandering Jew, and the Flying Dutchman: The Hunt In Wagner's Der fliegende Holländer. Intersections, 33(2), 19-34. https://doi.org/10.7202/1032693ar
Résumé de l'article

L'opéra de Richard Wagner, Le Vaisseau Fantôme, est une oeuvre inhabituelle en comparaison avec ses autres opéras de la même période, en raison de sa brièveté et du fait que ses sources sont moins familières pour le public. Étant donné que la légende du Hollandais volant était moins connue, Heine et Wagner l'ont mise en lien avec deux autres figures mieux connues : Heine présente le Hollandais comme le Juif errant, et Wagner, en donnant à sa musique un caractère de musique de chasse, le rapproche du Chasseur sauvage. Cet article examine les significations de ces associations en analysant les trois légendes et en montrant comment Wagner les utilise pour construire la structure dramatique et musicale de son opéra.
Copyright @ Canadian University Music Society / Société de musique des universités canadiennes, 2013
Ce document est protégé par la loi sur le droit d'auteur. L’utilisation des services d’Érudit (y compris la reproduction) est assujettie à sa politique d'utilisation que vous pouvez consulter en ligne.

https://apropos.erudit.org/fr/usagers/politique-dutilisation/ 


\section{THE WILD HUNTER, THE WANDERING JEW, AND THE FLYING DUTCHMAN: THE HUNT IN WAGNER'S DER FLIEGENDE HOLLÄNDER}

\section{J. Drew Stephen}

Der fliegende Holländer is unusual among Richard Wagner's mature operas for the brevity and relatively recent appearance of its source material. Compared to the rich web of medieval narratives and legends upon which Der Ring des Nibelungen, Tristan und Isolde, or Parsifal are based, the Flying Dutchman is a typically modern legend that did not achieve a definitive form until the nineteenth century. As Wagner acknowledged in an autobiographical sketch written contemporaneously with the opera, ${ }^{1}$ he found all the material he needed in a tale published by Heinrich Heine in 1834 . Heine's text, and his presentation of the tale as an ironic interlude within a larger narrative, is clearly modern, yet the story of a doomed individual condemned to an existence of eternal wandering is strongly grounded in the related traditions of older narratives and mythologies that intermingle to form complex layers of meaning. Heine alludes to these traditions by identifying the Dutchman as "that Wandering Jew of the ocean," and Wagner further expands the relationships by associating the Dutchman with hunting music to link him to the legends of the Wild Hunter. Although the Dutchman, in both Wagner's and Heine's versions, exists as a separate entity, much can be gained by considering this figure through a wider historical and narrative lens. This allows for an examination of the meanings accrued from the related legends and traditions while also defining how both Heine and Wagner perceived the Dutchman within these larger narratives. In the case of Wagner, it also provides insight into the narrative choices he made in developing the opera, particularly in his addition of the character of Erik.

Since all three legends are far less familiar today than they were for Wagner and his audience, I begin by reviewing them and establishing the relationships among them. I then move to Der fliegende Holländer to show how certain aspects of the legends provide structural and dramatic coherence in the opera while informing Wagner's changes and enhancements to the story. The result is a deeper awareness of the socio-cultural meanings of the opera and the cultural context in which it was first presented by Wagner and experienced by his audience.

1 An English translation of this statement can be found in Grey 2008, 57. 


\section{The Legends of the Flying Dutchman, the Wandering Jew AND THE Wild Hunter}

In order to approach the legends as they were understood in the nineteenth century, it is best to begin, as Wagner did, with Heine's version of the Flying Dutchman. Here is the essence of the tale as it was originally published by Heine in 1834:

The tale of the Flying Dutchman is no doubt familiar to you. It is the story of that doom-laden ship which can never gain the shelter of a port and which has roamed the seas since time immemorial ... A timbered specter, that dreadful ship bears the name of its captain, a Dutchman who once swore by all the devils in hell that he would round some cape or other (the name of which escapes me) in spite of the most violent storm that was then raging, even if he had to keep on tacking until the Day of Judgment. The devil took him at his word, and he is forced to roam the seas until the Day of Judgment, unless he can be saved by a woman's fidelity. Fool that he is, the devil does not believe in women's fidelity, and so he allowed the doomed captain to go ashore once every seven years to marry and in that way seek his salvation. ${ }^{2}$

Heine's version is notable for two main features. First, the Dutchman is a mortal man who is cursed because of a blasphemous act, and second, the curse results in a nomadic existence of eternal wandering. It is exactly these features that relate his legend to the legends of the Wandering Jew and the Wild Hunter.

If Heine, by referring to the Dutchman as the Wandering Jew of the ocean, was seeking to establish a broader understanding of the Dutchman for his readers by associating a relatively unknown figure with a familiar one, he was amply rewarded in his choice of legend. In contrast to the Flying Dutchman, the legend of the Wandering Jew or the Eternal Jew, as he is sometimes known, has a long history. It appears to have originated during the period of the Crusades and is mentioned in a number of thirteenth-century sources. By the end of the fifteenth century the legend was familiar across Europe. The 1602 publication of the anonymous Short Description and Tale of a Jew with the Name Ahasuerus (Kurtze Beschreibung und Erzehlung von einem Juden mit Namen Ahasverus) became the basis of the definitive account. This pamphlet, which appeared in twenty different editions in a single year in Germany alone (Cohen 2008, 148-49), was an enormous success that made the Wandering Jew familiar to a wide and diverse audience. As told in the pamphlet, Paulus von Eitzen, a doctor of theology and bishop of Schleswig, encountered a tall

2 "Die Fabel von dem Fliegenden Holländer ist euch gewiss bekannt. Es ist die Geschichte von dem verwünschten Schiffe, das nie in den Hafen gelangen kann, und jetzt schon seit undenklicher Zeit auf dem Meere herumfährt ... Jenes hölzerne Gespenst, jenes grauenhafte Schiff führt seinen Namen von seinem Kapitän, einem Holländer, der einst bei allen Teufel geschworen, dass er irgendein Vorgebirge, dessen Namen mir entfallen, trotz des heftigen Sturms, der eben wehte, umschiffen wollte, und sollte er auch bis zum Jüngsten Tag segeln müssen. Der Teufel hat ihn beim Wort gefasst, er muss bis zum Jüngsten Tage auf dem Meere herumirren, es sei denn, dass er durch die Treue eines Weibes erlöst werde." (Heine 1834; English translation in Grey 2000, 166-77) 
barefoot stranger in Hamburg in 1542 who identified himself as Ahasverus, ${ }^{3}$ a Jew by birth and a shoemaker by trade. Ahasverus tells von Eitzen that he lived in Jerusalem at the time of the crucifixion of Christ and since that time has remained alive and had travelled through many lands. Upon further questioning, Ahasverus explains that when he heard of Christ's sentencing by Pilate, he ran home and called his household to have a look at Christ and see what sort of person he was:

That having been done, he had his little child on his arm, and was standing in his doorway to have a sight of the Lord Jesus Christ. As Christ was led by, bowed under the weight of the heavy cross, he tried to rest a little, and stood still a moment. But the shoemaker, in zeal and rage, and for the sake of obtaining credit among the other Jews, drove the Lord Christ forward and told him to hasten on his way. Jesus, obeying, looked at him and said: "I shall stand and rest, but thou shalt go till the last day." At these words the man set down the child and, unable to remain where he was, he followed Christ and saw how cruelly he was crucified, how he suffered, how he died. As soon as this had taken place it came upon him suddenly that he could no more return to Jerusalem, nor see again his wife and child, but must go forth into foreign lands, one after another, like a mournful pilgrim. (Baring-Gould 1978, 22) ${ }^{4}$

The Wandering Jew's punishment effectively removes him from the normality of society while keeping him aware of his predicament to view how others are prospering. He is an outsider, but he is also able to assume a special role as a figure who is simultaneously local and alien. As an individual who is foreign and itinerant, his extensive travels and historical knowledge give him the authority to comment on current situations and warn against moral transgressions. This aspect is often emphasized by his familiarity with many languages and his ability to learn the subtleties of local dialects. During the age of Enlightenment, the Wandering Jew symbolized the voice of reason promoting curiosity, tolerance, and repentance. For the Romantic poets, Ahasverus become one of the great symbolic figures of this time, a representative of the mood of Weltschmerz or world-weariness that could be described as the underlying mood of the age (Borchmeyer 1991, 194). The Danish philosopher Søren Kierkegaard placed the Wandering Jew alongside the complementary figures of Don Juan and Faust to form what he called "a trio of three great ideas" that he viewed as "representing life in its three tendencies, as it were, outside of religion" (Pattison 2002, 75).

Like the Wandering Jew, the Wild Hunter or Eternal Hunter fits the formula of a familiar alien doomed to a sentence of eternal wandering. In this case, the punishment is the result of over-enthusiastic hunting, or of engaging in the activity, contrary to church rules, on solemn feast days. The Wild Hunter was originally a member of society but removed to become a supernatural figure

3 Occasionally, as in Wagner's writings, the name is spelled "Ahasuerus."

4 Originally published as Kurtze Beschreibung und Erzehlung von einem Juden mit Namen Ahasverus (Bautzen: Wolffgang Suchnach, 1602). 
who either leads his followers on a nightly hunt or is doomed to be pursued for eternity. In many cases, the Wild Hunter appears to mortals to warn them of his fate. The tale of the "Ewige Jäger" (Eternal Hunter) published in the German Legends of the brothers Grimm in 1816 presents the basic features of the legend and also serves as a warning against the inappropriate pursuit of pleasure:

Count Eberhard von Württemberg once felt the urge to go hunting for his amusement, and he rode out alone into the green forest. Suddenly, he heard a tremendous uproar as though a hunter were riding past through the sky. He was greatly frightened, and, after the apparition had dismounted onto a tree top, he asked the spirit if it intended to do him any harm. "No," replied the figure, "I am, like you, a human being and stand before you quite alone; I, too, was once a nobleman. However, I found so much joy in the hunt that I begged God to let me continue hunting until Judgment Day. Unfortunately, my wish was granted. I have now been pursuing the same stag for five hundred and fifty years."'s

Although the Wild Hunter occasionally appears on his own, he more often led an army of doomed spirits across the sky on a nightly hunt. He was accompanied by hunting calls and cries, the barking of dogs, and the neighing of horses. His followers were believed to be the souls of sinners, of people who hunted too enthusiastically in life, or simply individuals who encountered the Wild Hunter and were thus forced to follow him until Judgment Day. In some areas he was said to appear only in the twelve nights between Christmas and Epiphany, in others always when a storm wind howled. Although sometimes clothed in green, the traditional hunter's clothing, he was usually dressed in black and thus also referred to as the Black Huntsman. His mythological origins can be traced to Wuotan (or Wotan or Ode), the father of the gods, who also rode nightly through the sky accompanied by his followers. The so-called wilde Heer or wïthende Heer of spirits that follow him (literally "wild" or "enraged" army) is derived from Wuotans Heer (Wotan's army). ${ }^{6}$ Thus, in their origins, the Wild Hunter legends also provided Wagner with the material for Wotan, the wanderer figure who appears throughout Der Ring des Nibelungen.

With the shared focus of the Wild Hunter and Wandering Jew legends on eternal wandering as a punishment for a blasphemous act, it should come as no surprise that the two legends are closely related and even possibly derived from a single source. As Karl Blind argues, "The Wandering Jew has been evolved, as regards the main component parts of his individuality in Germany, from the

5 "Graf Eberhard von Württemberg ritt eines Tages allein in den grünen Wald aus und wollte zu seiner Kurzweil jagen. Plötzlich hörte er ein starkes Brausen und Lärmen, wie wenn ein Waidmann vorüberkäme; erschrak heftig und fragte, nachdem er vom Roß gestanden und auf eines Baumes Tolde getreten war, den Geist: ob er ihm schaden wolle? „Nein“, sprach die Gestalt, „ich bin gleich dir ein Mensch und stehe vor dir ganz allein, war vordem ein Herr. An dem Jagen hatte ich aber solche Lust, daß ich Gott anflehte, er möge mich jagen lassen bis zu dem Jüngsten Tag. Mein Wunsch wurde leider erhört, und schon fünfthalb hundert Jahre jage ich an einem und demselben Hirsch." (Translation in Ward 1981, 245)

6 For more on the German legends of the wild hunt, see Beurmann 1961, Grässe 1885, and Meisen 1935. 
figure of the Wild Huntsman, who himself is probably a later mask of the chief Teutonic deity Wodan, or Odin" (Blind 1986, 174). As evidence, Blind notes that in parts of Swabia and the Black Forest, the Eternal Hunter and the Eternal Jew are regarded as the same person, and both expressions are used there as identical (ibid., 182).7 The common origin of the two legends also explains unusual versions featuring a forest-haunting or hill-enchanted Jew (ibid., 185) or the practices of farmers in some parts of Germany to arrange the rows in their fields a certain way or place the harrows in the field with the teeth together to provide the Wandering Jew with a resting place. According to some authorities, the Wandering Jew was allowed respite only on Christmas night and only when he found a plough in the field on which to sit (Baron 1967, 178; and Lauder 1881, 125-26). There is even a conflated version of the two legends that emerged sometime in the Middle Ages in which the Wild Huntsman is a Jew who refuses to allow Jesus to drink from his well but instead points to a hoof-print in which a little water had collected. For this indignity, the Jew is condemned to wander for eternity (Anderson 1965, 5-6; and Baring-Gould 1978, 25). Heine and Wagner were not alone in drawing this connection in the nineteenth century. In Levin Schückling's 1851 short story "Die drei Freier," the three suitors of the title are Ahasverus, the Flying Dutchman, and the Wild Huntsman. The object of their courtship is a young woman emancipated by her young German ideals whom they attempt to convert to true womanhood (Borchmeyer 1991, 200-01).

Heine and Wagner may have been compelled to associate the Flying Dutchman with the Wild Hunter and the Wandering Jew partly because of the widespread credibility of both legends. People across Europe and even as far away as Iceland contended that they had personally seen the Wandering Jew. During the nineteenth century, museums in Ulm and Berne even displayed large shoes that were allegedly worn by the Wandering Jew (Baron 1967, 181; Blind 1986, 186). The same was true of the Wild Hunter. Many versions of the legend are presented as actual occurrences, and German encyclopedias, even as late as 1935, asserted that the Wild Hunter legend was a living folk belief in some areas. ${ }^{8}$ The French King Henri IV reportedly encountered the Wild Hunter in 1598. During a hunt, the king and his hunting party were interrupted suddenly by the sounds of barking dogs, cries, and horn calls from another group of huntsmen. When they investigated, they encountered only a single huntsman dressed in black who called from the thick underbrush and then mysteriously disappeared. The king was shaken by the experience, and it was later interpreted as the first in a series of bad omens that preceded the death of his mistress, Gabrielle d’Estrée. ${ }^{9}$

7 See also Lauder 1881, 126.

8 Große Brockhaus (Leipzig: F.U. Brockhaus, 1928-35), s.v. "Wilde Jagd."

9 Grand Dictionaire Universel du XIXe Siècle, 1865 ed., s.v. "Veneur." The Wild Hunter legends in France are also discussed in Ambelain (1981, 44-52). 


\section{The Flying Dutchman as Wild Hunter}

In his autobiographical Communication to My Friends of 1851 (Grey 2000, 18185) Wagner addresses in detail his conception of the Flying Dutchman as a mythic-poetic creation of the folk in which the figure of Odysseus is recreated in the guise of the Wandering Jew. Although he had earlier credited Heine's ironic interlude as his source of inspiration, Wagner, in this later document, relocates the Dutchman's origins to legend and myth. As Stephen McClatchie points out, the omission of Heine and the mythologizing of the Dutchman legends allow Wagner to reshape and interpret the material in artistic form, just as he was to do with the Nordic and German myths that became the Ring (McClatchie 2012, 887). Wagner's shift to a mythological origin also points to the related legends of the Wild Hunter.

With a close connection between the Wandering Jew and Wild Hunter already well established in legend and cultural belief, it is not difficult to see why Wagner would turn to this latter tradition for the dramatic and musical possibilities. Whereas the Wandering Jew is virtually absent from the operatic repertoire, the Wild Hunter appears in numerous operas, allowing Wagner and his audience to draw on well-known precedents. The Wild Hunter legends also brought in sinister and demonic elements that were clearly useful in Wagner's conception of this figure and would allow him to emphasize his underlying theme of redemption. With the Flying Dutchman characterized as a hunter, even metaphorically, there is justification of Erik's role as a hunter and the establishment of a pattern of opposites with a strong dramatic function in the narrative. Most significant, the Wild Hunter was associated with a distinct, clearly recognizable, and well-defined set of musical gestures that supplied Wagner with a rich musical means to portray the Dutchman in music. It was this last item that Wagner must have found most compelling and that he used with particular elegance and imagination from the opening notes of the overture.

The opening of Der fliegende Holländer is widely understood as representing a ferocious maritime storm that stands out as exceptional among storms in the symphonic and operatic repertoire. The widely spaced open fifths in the high strings and winds convey an awesome sense of nature's raw power, the muscular perfect-fourth and fifth gestures and accented grace notes in the horns suggest the relentless pounding of the sea, and the rumbling line in the violoncellos and basses that rises out of the depths like a giant and foreboding wave captures the menacing rage of the storm (example 1).

Listening to this music, it is easy to envision the howling wind, the crashing waves, and the precarious progress of the Dutchman's vessel on the stormy sea. Since this same music is associated with the Flying Dutchman throughout the opera, we are compelled to seek in it elements of his personality as well. Indeed, it is easy to hear suggestions of his brooding and tormented nature and of the pride and persistence that led to his blasphemous defiance of God and that he continues to demonstrate in his relentless pursuit of the terms of the curse.

While this interpretation seems appropriate in light of the opera's plot, the stylistic codes and conventions of nineteenth-century music point not to the 

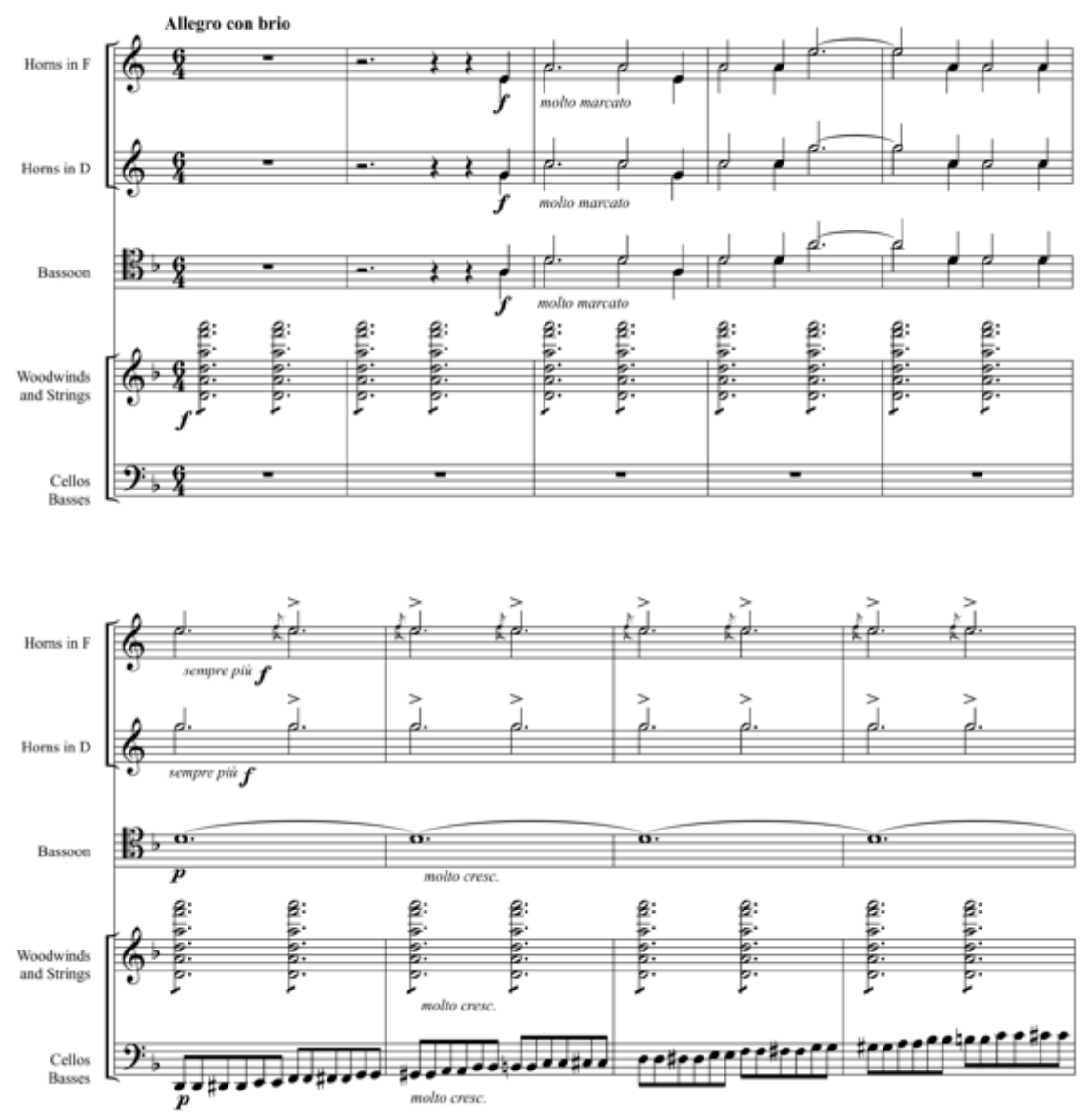

Example 1. Wagner, Der fliegende Holländer: overture, mm. 1-9

sea and stormy weather, but to the musical topic of the hunt. The overture begins in $\mathrm{D}$, the key of the traditional French trompe de chasse or hunting horn and a key often used for pieces that evoke the hunt. ${ }^{10}$ It is in a compound metre, specifically, 6/4, with an emphasis on trochaic rhythms that are frequently used in the hunting topic to recall a horse's gallop. Finally, there is the dominating presence of the horns, a very powerful signifier of the hunt. ${ }^{11}$

The metre, key, and prominent use of the horn are already powerful signifiers of the hunt that Wagner further reinforces with distinctive musical gestures

10 To cite just two well-known examples, the Overture from Étienne Nicolas Méhul's Le jeune Henri (1797), and the hunting chorus, "Was gleicht wohl auf Erden” from Carl Maria von Weber's Der Freischütz (1821)

11 This draws on the tradition acknowledged by E.T.A Hoffmann when he noted that "certain horn melodies momentarily transport the listener to forests and fields, which may well be more than just a consequence of the horn's association with the forest-dwelling huntsman." See Hoffmann's review of Méhul's Overture La Chasse du jeune Henri, originally published in the Allgemeine musikalische Zeitung xiv, 11 November 1812, cols. 743-7. English translation in Charlton 1989, 298. 
that were well established within the hunting topic. The horn melody at the beginning of the overture is a powerful call that opens with the rising gesture of a perfect fourth followed by a perfect fifth on notes that correspond to the sixth, eighth, and twelfth pitches of the harmonic series. Two elements-the muscular rhythms and perfect fourth opening that moves from the dominant to the tonic while remaining within the confines of the harmonic series-are typical of authentic horn calls and characterize this melody as a hunting call. The connection to the hunt is further strengthened when the melody returns in Senta's Ballad in act 2 and is vocalized with the syllables "jo-ho-hoe!" (example 2).

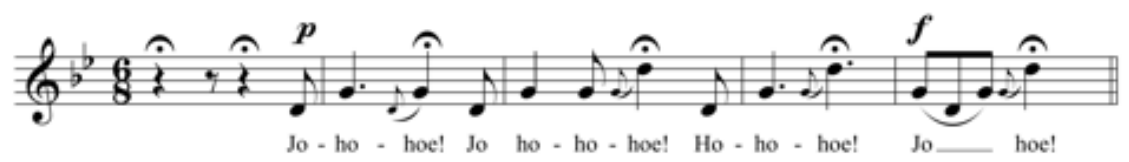

Example 2. Wagner, Der fliegende Holländer: Act 2, Senta’s Ballad

The syllables used by Wagner are characteristic of the repertoire of hunting calls and cries. Heinrich Döbel describes their use in a ritualized punishment for a breech of etiquette in his Jäger-Practica of 1746:

The pine boughs are removed from the worthiest of the huntable stags, and he who is to be the recipient of the hunting knife lies across it and meanwhile sets aside his weapons ... He who has committed the offense, must lift his tunic over his backside, and receive on the exposed breeches, three blows [with the broadside of the hunting knife]. As the hunting master takes out his hunting knife, the attending hunters take their horns and play. With the first blow, the hunting master recites in a clear voice: Jo ho! that is for my merciful and gracious prince and master; with the second: Jo, ho! that is for knight, cavalryman, and valet; with the third: Jo ho! that is for the noble right to hunt. Thereupon, the hunters conclude with a hunting cry. However, he who received the hunting knife must thank the others reverently. (Döbel 1746, 240-41) ${ }^{12}$

Carl Maria von Weber also used the syllables in the refrain of the Huntsmen's Chorus, "Was gleicht wohl auf Erden" from Der Freischütz (1821), in which the hunters intone, "Jo, ho! Tralalala!" at the end of each verse. Although these are simple syllables that allow Senta to vocalize the horn melody, they are clearly grounded in strong associations of the hunt.

12 Es werden von den besten jagdbaren Hirschen die darauf gedeckten Brüche abgehoben, darüber muß sich derjenige, so das Weidemesser krieget, legen und sein anhabendes Seitengewehr unterdessen und so lange ablegen ... Der, so sich vergangen, den Rock über den Poder aufnehmen muß, und kriegt er sodenn auf die bloßen Hosen drei Pfund. Wenn nun der Oberjägermeister das Weidemesser herausgezogen, so nehmen die dabei herumstehenden Jäger ihr Hifthörner und blasen. Bei dem ersten Streiche spricht der Oberjägermeister mit wohllautender Stimme: Jo ho! das ist vor meinen gnädigsten Fürsten und Herrn; bei dem andern: Jo ho! das ist vor Ritter, Reiter und Knecht; bei dem dritten: Jo ho! das ist das edle Jägerrecht. Darauf die Jäger mit einem Waldgeschrei beendiget. Derselbe aber, welcher das Weidmesser emfangen, muß sich alsdenn mit einem Reverence bedanken. (All translations are the author's, except where otherwise noted.) 
After the opening gesture of the horn call in Wagner's overture, the horns continue with accented grace notes on the strong beats of each bar. This type of accented grace note recalls an effect that is characteristic of a hunting-horn performance style known as the tayauté. The tayauté itself is an imitation of the hunting cry, taïaut, shouted by hunters to encourage the hounds when they make visual contact with the quarry. It is similar in use to the English term tallyho, which is probably derived from it. Tyndare-Gruyer, in his huntinghorn method of 1889, describes the significance of the tayauté as "an unexpected burst of sound, a sort of rhythmic barking, a harmonious tearing of the voice" (Tyndare-Gruyer 1889,14 ). In performance, the tayauté is realized as an ornamental mordent. As horn-player Daniel Bourgue explains, "The tayauté is related to the Baroque trill. It is a sort of doubling of a long note in which the second note is like an echo of the first ... The tayauté has also been compared to the effect of the human voice yodeling" (Bourgue 1982, 30).

If Wagner were seeking to connect the accented grace notes of the overture, not just to the hunt, but specifically to the Wild Hunter, he had two strong precedents in operatic works that were familiar to him. The first occurs during the casting of the bullets in the Wolf's Glen scene (act 2 finale) of Weber's Der Freischütz (example 3). As Caspar and Max cast the fifth bullet, the wilde Heer (the army of the Wild Hunter's followers) pass overhead, accompanied by the sounds of baying hounds and neighing horses. As the third and fourth horns in E play a relentlessly driving rhythmic figure, the first horn in B-flat alto plays a demonic call characterized by upper grace notes. In this range and at this dynamic-Weber asks that the entire passage be played sempre tutto fortissimo possibile - the B-flat alto crook has a harsh and penetrating timbre that is ideally suited to the dramatic situation. By writing both the first horn in B-flat and the third and fourth horns in $\mathrm{E}$ on the tenth harmonic (a notated $\mathrm{E}$ ), Weber cleverly obtains the interval of an augmented fourth, a demonic perversion of the perfect fourth interval that opens many horn calls.

Wagner's second precedent appears in Heinrich Marschner's Hans Heiling of 1833. As Anna's mother Gertrude awaits Anna's return from the forest with growing concern, she listens to the howling wind and draws a connection between the storm and the Wild Hunter:

\begin{tabular}{|c|c|}
\hline GERTRUDE: & GERTRUDE: \\
\hline Heihei, das stürmt ja, & It storms, \\
\hline als wäre das wilde Heer los & as if the wild huntsmen were out \\
\hline \multicolumn{2}{|l|}{ [Noticing the howling dogs] } \\
\hline GERTRUDE: & GERTRUDE: \\
\hline Wie die Hunde in den Sturm heulen. & How the dogs howl in the storm. \\
\hline 's ist shaurig kalt & It is dreadfully cold. \\
\hline
\end{tabular}

At Gertrude's mention of the dogs, a faint hunting call, consisting of accented grace notes, is sounded by the horns in the orchestra. This suggests that these are not just any dogs, but the ghostly ones that accompany the army of the Wild Hunter (example 4). 

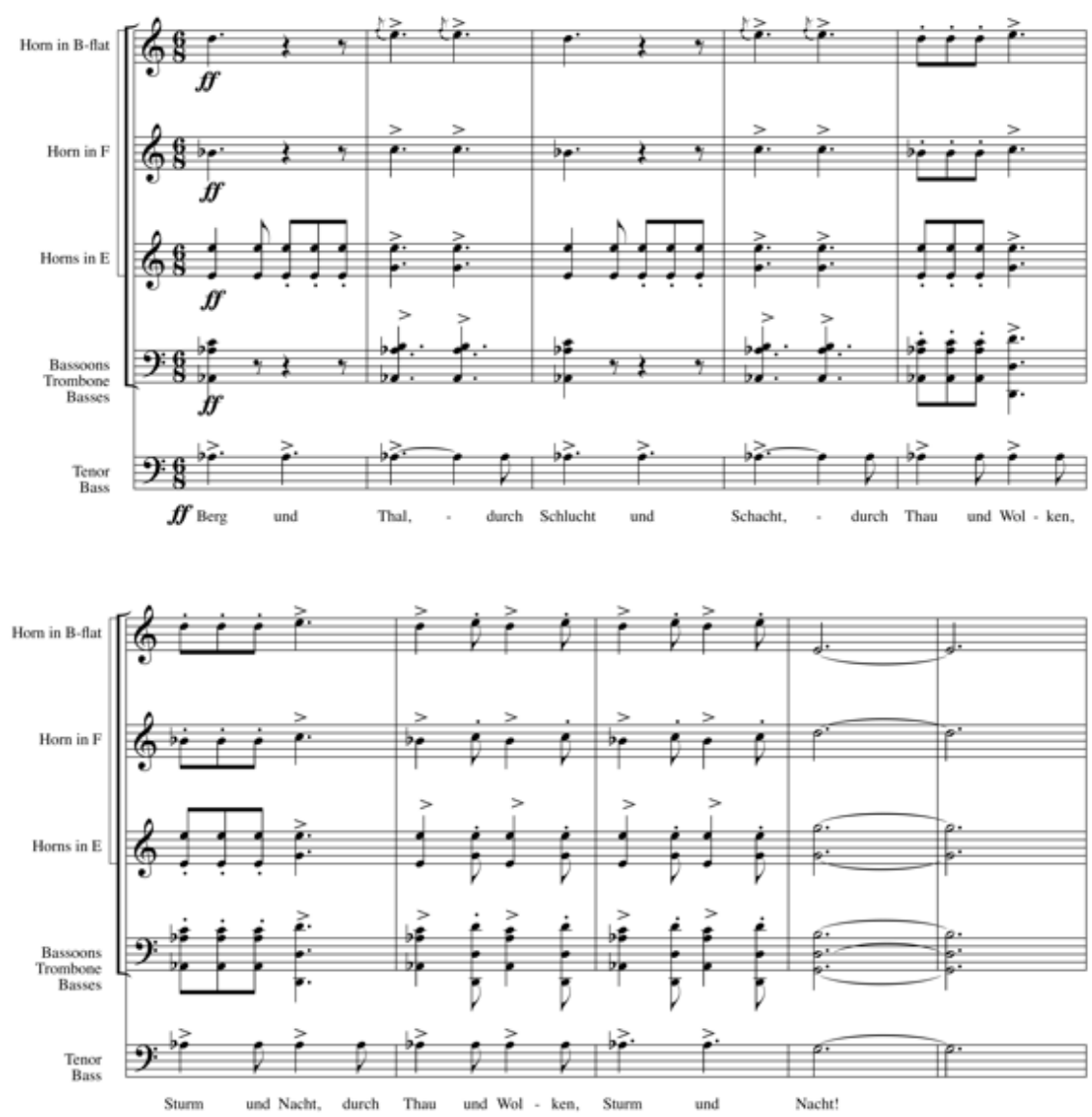

Example 3. Weber, Der Freischütz: Act 2 finale, mm. 347-356

The final reference to the hunting topic in Wagner's overture occurs at the end of the opening section. As the music subsides, the horn-call motif can be heard dying out in the distance, first in the horns, and then in the lower strings, as if moving away from the listener. Since the sounds of the hunt were perceived by most listeners from a distance, composers often evoked the hunt by imitating the effect of having the music recede farther and farther from the listener. Wagner achieves this by reducing the dynamic to piano, through a change in timbre from horn to the softer sound of the low strings, and finally by reducing the motif from its original seven notes to five notes to two notes, to a single note on the timpani, and finally to silence.

The overture of Der fliegende Holländer demonstrates so many features of the hunting topic that, were it not for the dramatic situation and maritime setting, it would surely be placed alongside Mehul's Chasse de jeune Henri, Franck's Le Chasseur maudit, and Berlioz's "Chasse royal et orage" from Les Troyens as one of the great evocations of hunting in the symphonic repertoire. Since Wagner's overture clearly does not depict a hunt, one must assume that 


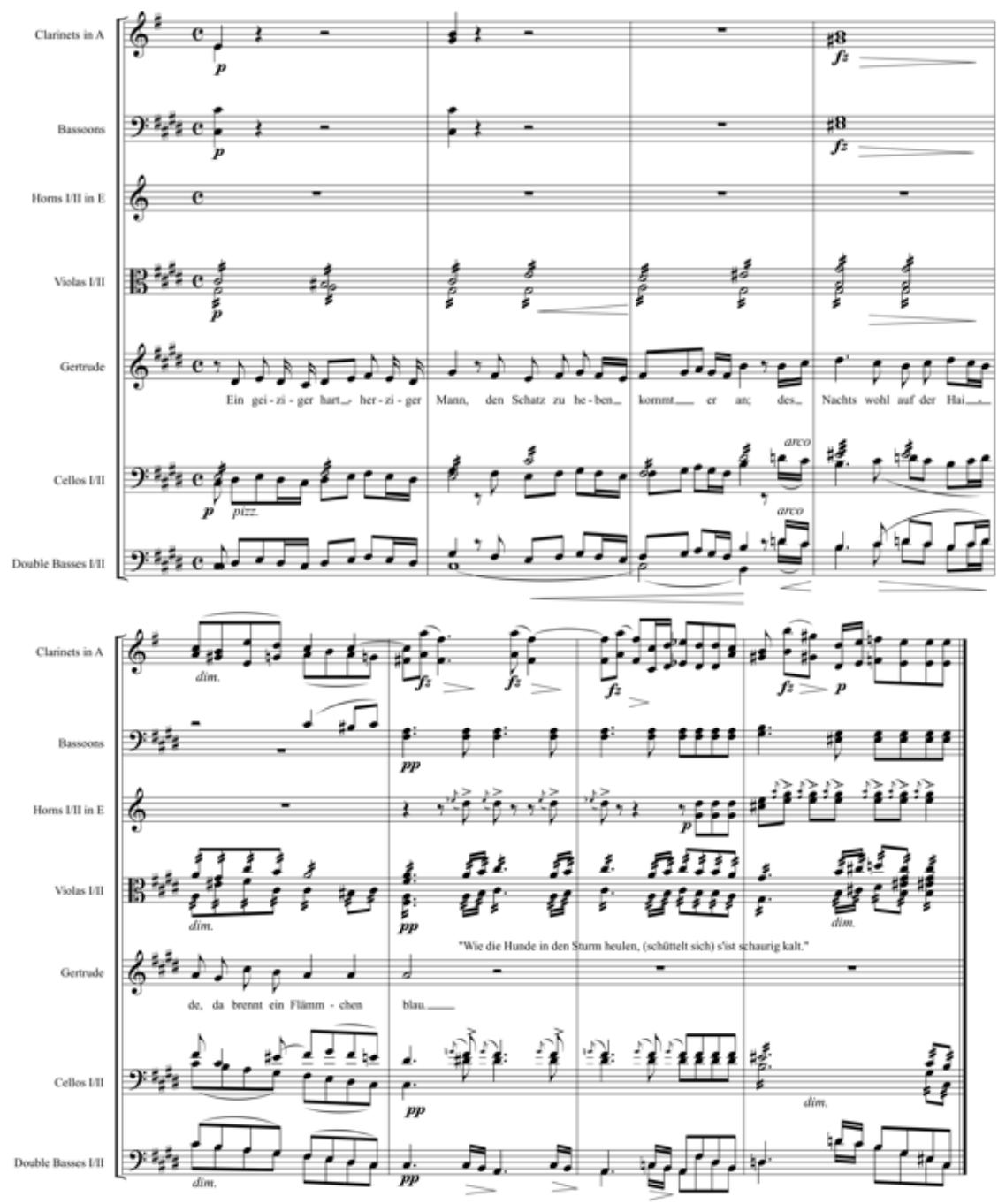

Example 4. Marschner, Hans Heiling: Act 2 Melodram und Lied

Wagner was using the hunting topic as a means of establishing the character of the Flying Dutchman, with whom this music is closely associated. Since the legends of the Flying Dutchman and the Wild Hunter are so similar, the hunting topic reinforces and strengthens the connection.

\section{Erik and the Flying Dutchman}

Before considering the Flying Dutchman in the context of the hunting topic, it is necessary to establish Erik's role in the opera. Unlike the Dutchman, Erik is identified in the libretto as a hunter and, of course, dresses and acts the part onstage. Despite the fact that he is singularly out of place in this maritime 
setting, the character of Erik and his hunting identity are Wagner's invention, suggesting that Wagner felt both the character of Erik and his hunting identity were significant in the narrative. Although no such character appears in Heine's story, a "young man, good hearted but poor," who is "passionately in love" with the merchant's daughter and troubled by "strange and dreamlike inclinations of her" can be traced to the earliest surviving document connected with Wagner's opera, the original French prose draft of 1840 (Grey 2000, 169-73). At this point neither the daughter nor the young man is given a name, but it is clear that the young man competes with the Dutchman for the young woman's affections. In the subsequent German prose sketch of 1840 or 1841, Wagner identifies the young man and woman as Georg and Anna and writes a scene in which Georg, who "raves like a madman," confronts Anna in a jealous rage over her association with the Dutchman (173-78). The names are certainly appropriate to the Scottish setting that Wagner still had in mind at this point but also significant since a character called Anna would recall Marschner's Hans Heiling of 1833 in which the heroine, Anna, is saved from her engagement to a mysterious, supernatural figure by a hunter whom she loves. Although the exact opposite occurs in Wagner's opera, Wagner must have been drawn by the scenario and aware of the similar situation in his own opera. By the time Wagner completed the first manuscript libretto and orchestra score of Der fliegende Holländer, Senta's fiancé-and the Dutchman's rival for her affections-was identified as a hunter.

With the hunting topic fully developed and at the height of its use by the middle of the nineteenth century, Wagner had compelling reasons for presenting Erik as a hunter in the opera, especially in terms of establishing and ultimately thwarting audience expectations. First of all, the heroic hunter was widely understood to be attractive to women. ${ }^{13}$ Erik's hunting identity makes him an obvious choice as Senta's suitor if he is to contend with the Dutchman for Senta's affections, because, as a hunter, he represents a formidable obstacle that must be overcome by the Dutchman. Senta's rejection of Erik in favour of the Dutchman is thus given added impact as shocking and profound, since it is contrary to established conventions. Second, Wagner could draw on a strong tradition of hunters confronting supernatural or evil figures and emerging victorious. This is the scenario presented in Marschner's Hans Heiling in which the hunter Konrad saves Anna from Heiling, the prince of the earth spirits. It also appears in Weber's Euryanthe (1823), in which the huntsmen discover and rescue Euryanthe from a dragon-inhabited wilderness where she has been abandoned. It would appear again in Schumann's Genoveva (1850), in which the hunters rescue Genoveva from the villain Golo and reunite her with her husband, Siegfried. Since Wagner, by identifying Erik as a hunter, alludes to this tradition so strongly, Erik's inability to save Senta from the Dutchman becomes almost unthinkable at the time and was certainly understood as a

13 A well-known example can be found in Schubert's song cycle of 1823 , Die schöne Müllerin, based on poems by Wilhelm Müller in which a journeyman miller falls in love with the miller's daughter but cannot compete with the hunter, who easily wins her affections. This theme is addressed in detail in Youens 1997. 
striking subversion of conventions. Finally, Erik's identity as a hunter establishes a relationship between him and the Dutchman. It is notable that apart from the muffled horn calls that are heard as Erik begins to recount his dream (act 2), the hunting music in the opera is associated not with Erik, whose identity as a hunter is already explicit, but reserved instead for the Dutchman. By associating the Dutchman with hunting music and identifying Erik as a hunter in the libretto, Wagner presents both of them as hunters, albeit at opposite extremes of the identity: one as an earthly hunter, the other as a spiritual hunter. In doing so, Wagner is able to realize his vision of achieving the Dutchman's transfiguration and redemption.

\section{Senta, Erik, ANd the Flying Dutchman}

Erik is the model of the heroic huntsman. He is brave, loyal, attractive to women, and grounded in the natural world of the forest. Like all heroic hunters, he represents worldly pleasure, earthly existence, and the vibrancy of life. In his "Remarks on the Performance of the Opera Der fliegende Holländer" of 1852, Wagner describes Erik as being "of a stormy temperament, sturdy and somber, like the lonely northern highlands themselves (Grey 2000, 200). By contrast, the Dutchman is a spiritual hunter, a figure who has been condemned to navigate the seas aimlessly, longing for release from a worldly existence. It is only through death that he will find peace. Together, the Dutchman and Erik form a pattern of opposites: the worldly hunter concerned with life in the present and the supernatural hunter concerned with death and redemption. Senta, in choosing the Dutchman over Erik, is not making a choice between two individuals, but between the worldly and the spiritual. By renouncing the worldly, represented by Erik, she is able to embrace the spiritual, the Dutchman, and remain true to him unto death to bring about their transfiguration. Senta's choice here is crucial, and it is the gravity of the choice that Wagner felt must be conveyed, for it is on this point that the legend of the Flying Dutchman departed from that of the Wandering Jew and the Wild Hunter. As Wagner explains in A Communication to My Friends, the Dutchman, like Ahasverus, "yearns for an end of his sorrows through death. But this redemption, withheld from the Wandering Jew, is put within reach of the Dutchman in the form of a woman who will sacrifice herself for love. The longing for death drives him to seek out such a woman" (182).

Wagner was well aware of the significance of the legend of the Flying Dutchman on his artistic development. "It was the first popular myth," he noted in A Communication to My Friends, "to penetrate my heart and compel me, as a creative artist, to reshape it and interpret it in artistic form. From this point," he continued, "my career as a poet begins, while that as a mere manufacturer of opera libretti ceases" (Grey 200o, 182). Wagner found many themes in the legend that resonated strongly with him and would recur in his oeuvre, notably the yearning for an end to sorrow through death and the possibility of redemption in the form of a woman who will sacrifice herself for love. The similarities among the Flying Dutchman, Wandering Jew, and Wild Hunter legends 
offered Wagner the possibility of an eloquent and sophisticated application of the hunting topic. From Heine's parodistic tale in the form of a stage play about the Flying Dutchman and the off-hand comment that the Dutchman was the Wandering Jew of the ocean, Wagner was able to craft a story that equated existence with suffering in a way that captured the underlying Weltschmerz of the age while also realizing the goal of peace in the form of redemption and transfiguration. Wagner's use of the hunting topic to characterize the Dutchman not only adds depth to the opera by associating this figure with the Wild Hunter, it makes possible the relationship between the Dutchman and Erik as spiritual and worldly hunters who vie for Senta's affections. It was a brilliant demonstration of Wagner's skills as a poet and also an adept use of the hunting topic that Wagner would turn to again in the hunting music of Tannhauser, Tristan und Isolde, and Götterdämmerung.

\section{REFERENCES}

Abbate, Carolyn. 1988. “Erik's Dream and Tannhäuser's Journey." In Reading Opera, ed. Carolyn Abbate and Roger Parker, 129-67. Berkeley: University of California Press.

Ambelain, Robert. 1981. Symbolism et rituel de la chasse à courre. Paris: Éditions Robert Laffont.

Anderson, George K. 1965. The Legend of the Wandering Jew. Providence, RI: Brown University Press.

Baring-Gould, Sabine. 1978. Curious Myths of the Middle Ages. New York: Oxford University Press.

Baron, Salo Wittmayer. 1967. A Social and Religious History of the Jews. Vol. 11, Citizen or Alien Conjurer. New York: Columbia University Press.

Beurmann, Arno. 1961. Der Aberglaube der Jäger: Von der beseelten Magie, von Mystik und Mythen und allerlei Zauberwahn der Jäger. Hamburg: Verlag Paul Parey.

Blind, Karl. 1986. "Wodan, the Wild Huntsman, and the Wandering Jew." In The Wandering Jew: Essays in the Interpretation of a Christian Legend, ed. Galit Hasan-Rokem and Alan Dundes, 169-89. Bloomington: Indiana University Press.

Borchmeyer, Dieter. 1991. "The Transformations of Ahasuerus: Der fliegende Holländer and His Metamorphoses." In Richard Wagner: Theory and Theatre, trans. Stewart Spencer, 190-215. Oxford: Clarendon.

Bourgue, Daniel. 1982. "La tompe de chasse, histoire, technique musicale." Brass Bulletin 39:26-38.

Charlton, David. 1989. E.T.A. Hoffmann's Musical Writings: Kreisleriana, the Poet and the Composer, Music Criticism. Cambridge: Cambridge University Press.

Cohen, Richard I. 2008. “The 'Wandering Jew' from Medieval Legend to Modern Metaphor." In The Art of Being Jewish in Modern Times, ed. Barbara Kirshenblatt-Gimblett and Jonathan Karp, 147-75. Philadelphia: University of Pennsylvania Press. 
Döbels, Heinrich Wilhelm. 1746. Eröffnete Jäger-Practica, Oder Der wohlgeübte und Erfahrne Jäger. Reprint, Neudamm: J. Heumann, 1913.

Grässe, Johann Georg Theodor. 1844. Die Sage vom Ewigen Juden historisch entwickelt, mit verwandten Mythen verglichen und kritisch beleuchtet. Dresden: Arnoldische Buchhandlung.

—. 1885. Jägerbrevier. 2nd rev. ed. Berlin: Paul Parey.

Grey, Thomas, trans. 2008. "Richard Wagner: Autobiographical Sketch (to 1842)." Wagner Journal 2:42-58.

— ed. 2000. Richard Wagner, Der fliegende Holländer, Cambridge Opera Handbooks. Cambridge: Cambridge University Press.

Heine, Heinrich. 1834. “The Fable of the Flying Dutchman." Aus den Memoiren des Herren von Schnabelewopski, chapter 7. Originally published in Der Salon I, n.d. (Hamburg: Hoffmann \& Campe).

Knecht, Edgar. 1977. Le mythe du Juif errant: Essai de mythologie littéraire et de sociologie religieuse. Grenoble: Presses universitaires de Grenoble.

Lauder, Toofie. 1881. Legends and Tales of the Harz Mountains. London: Hodder and Stoughton.

McClatchie, Stephen. 2012. "The Flying Dutchman, the Wandering Jew, and Wagner's Anti-Semitism." University of Toronto Quarterly 81 (4): 877-92.

Meisen, Karl. 1935. Die Sagen vom Wütenden Heer und Wilden Jäger. Münster: Aschendorffsche Verlagsbuchhandlung.

Pattison, George. 2002. Kierkegard, Religion, and the Nineteenth-Century Crisis of Culture. Cambridge: Cambridge University Press.

Tyndare-Gruyer. 1889. Méthode Complète de Trompe de Chasse. Paris: Rallie-Provence.

"Veneur." In Grand Dictionaire Universel du XIX ${ }^{e}$ Siècle. Paris: Larousse, 1865. Ward, Donald, ed. 1981. The German Legends of the Brothers Grimm. Vol. 1. Philadelphia: Institute for the Study of Human Issues.

Weiner, Marc. 1995. Richard Wagner and the Anti-Semitic Imagination. Lincoln: University of Nebraska Press.

"Wilde Jagd." 1935. In Große Brockhaus, 325. Leipzig: F.U. Brockhaus.

Youens, Susan. 1997. Schubert, Müller, and Die schöne Müllerin, 42-100. Cambridge: Cambridge University Press.

\begin{abstract}
Richard Wagner's Der fliegende Holländer is unusual among the composer's mature operas for the brevity and relative unfamiliarity of its source material. Since the legend of the Flying Dutchman was relatively unknown, both Heine and Wagner contextualize the Dutchman by relating him to better-known figures: Heine refers to the Dutchman as the Wandering Jew, and Wagner, through hunting music, connects him to the Wild Hunter. This article addresses the significance of these associations by examining the meanings of all three legends and demonstrating how they are used by Wagner to provide dramatic and musical structure in the opera.
\end{abstract}




\section{RÉSUMÉ}

L'opéra de Richard Wagner, Le Vaisseau Fantôme, est une œuvre inhabituelle en comparaison avec ses autres opéras de la même période, en raison de sa brièveté et du fait que ses sources sont moins familières pour le public. Étant donné que la légende du Hollandais volant était moins connue, Heine et Wagner l'ont mise en lien avec deux autres figures mieux connues: Heine présente le Hollandais comme le Juif errant, et Wagner, en donnant à sa musique un caractère de musique de chasse, le rapproche du Chasseur sauvage. Cet article examine les significations de ces associations en analysant les trois légendes et en montrant comment Wagner les utilise pour construire la structure dramatique et musicale de son opéra. 